\title{
Human resources
}

'The public library has to be organised effectively and professional standards of operation must be maintained.

The librarian is an active liaison between users and resources. Professional and continuing education of the librarian is indispensable to ensure adequate services.'

(IFLA/UNESCO Public Library Manifesto, 1994)

\subsection{Introduction}

Staff are a vitally important resource in the operation of a library. Staff expenses normally represent a high proportion of a library's budget. In order to provide the best possible service to the community it is necessary to maintain well trained and highly motivated staff to make effective use of the resources of the library and to meet the demands of the community. Staff should be available in sufficient numbers during all hours to carry out these responsibilities.

The management of library staff is itself an important task. All staff should have a clear understanding of the policy of the library service, well-defined duties and responsibilities, properly regulated conditions of employment and salaries that are competitive with other similar jobs.

\subsection{The skills of library staff}

As the demands on libraries become more diverse, specific skills of staff are required beyond what is found in a general job description. Competencies to attain these skills may be learned through on the job training, continuing education or based upon prior experience. Staff skills traditionally related to the practices and procedures of the organisation, but now and more often relate to technology, customer service 
and interpersonal skills. The fundamental qualities and skills often required of staff can be defined as:

- the ability to communicate positively with people

- the ability to understand the needs of customers

- the ability to co-operate with individuals and groups in the community

- knowledge and understanding of cultural diversity

- knowledge of the material that forms the library's collection and how to access it

- an understanding of and sympathy with the principles of public service

- the ability to work with others in providing an effective library service

- organisational skills, with the flexibility to identify and implement changes

- teamwork and leadership skills

- imagination, vision and openness to new ideas and practice

- readiness to change methods of working to meet new situations

- knowledge of information and communications technology as these change.

- Queensland Standards and Guidelines for Public Libraries (see Appendix 6, 2. Staffing standards) offers a link <http://www.alia.org.au/policies/core.knowledge.html> to criteria for staff skills and attributes issued by the Australian Library and Information Association.

- WebJunction includes a list of American Library Association (ALA) and US state library organisations' staff competencies within the Competency Index. <http://www.webjunction.org/competencies>

\subsection{Staff categories}

The following categories of staff are found in public libraries:

- qualified librarians

- library assistants

- specialist staff

- support staff.

In some countries there is an additional category of library technician, or para-professional, with an intermediate level of qualifications. 
Staff in all categories may be appointed on either a full-time or parttime basis. In some countries two or more people share a single post, a practice known as job-sharing. This provides the opportunity to appoint and retain experienced staff that may not be able to work full-time.

\subsubsection{Qualified librarians}

Qualified librarians are professional staff who have undertaken a course of study in librarianship and information studies to degree or post-graduate level. A librarian designs, plans, organises, implements, manages and evaluates library and information services and systems to meet the needs of the customers in the community. This will include collection development, the organisation and exploitation of resources, the provision of advice and assistance to customers in finding and using information and the development of systems that will facilitate access to the library's resources. Qualified librarians must know and understand the community and have regular contact with members of the community that they serve. Expertise in specific areas, for example, management, children's materials and services and reference should be encouraged as needed, and when forming the professional team.

The following is a list of some of the duties of the qualified librarian. This list is not exhaustive nor is it likely that the qualified librarian will undertake all these activities simultaneously:

Planning and administration:

- analysing the resource and information needs of the community

- formulating and implementing policies for service development

- planning services for the public and participating in their delivery

- developing acquisition policies and systems for library resources

- managing and administering library and information services and systems

Information provision:

- retrieving and presenting information

- answering reference and information enquiries using appropriate material

- assisting customers in the use of library resources and information

- providing readers' advisory services 
Marketing:

- developing services to meet the needs of special groups, e.g., children

- promoting library services

- advocating for libraries, services and staff

Information organization:

- creating and maintaining databases to meet the needs of the library and its customers

- designing library and information services and systems to meet the needs of the public

- cataloguing and classification of library materials

- keeping up-to-date with current developments in the information profession and relevant technologies

Evaluation and monitoring:

- evaluating library services and systems and measuring their performance

- selecting, evaluating, managing and training staff

Facility management:

- participation in planning the design and layout of new and refurbished libraries and of mobile libraries

Collection development:

- selecting and purchasing library materials for stock

- developing reading with customers

Customer education:

- providing educational and training opportunities for the community

- developing services to meet the needs of special groups.

\subsubsection{Paraprofesional staff}

The duties of paraprofessional staff may typically include: supervision of non-professional staff and staff scheduling; routine public and technical service functions; and building and facilities maintenance. They 
will often be experienced staff who the public will come into contact with most frequently. It is essential, therefore, that they should have a high level of interpersonal and communication skills and receive appropriate training. These positions may offer opportunity for education and career development into professional librarian positions.

\subsubsection{Library assistants}

Library assistants may most often be employed by larger public libraries to carry out routine and operational library tasks such as circulation activities, shelving, processing library materials, data entry, filing, clerical support and greet and direct customers. They may also assist with children's programming and arts and crafts.

\subsubsection{Specialist staff}

Larger public libraries may employ specialist staff to carry out specific functions, for example, computer system managers, administrative, financial, facility engineers, training and marketing staff. Specialist staff generally have a qualification in their specialty area rather than in librarianship.

\subsubsection{Support staff}

Support staff include caretakers, cleaners, drivers and security staff. They carry out important functions, which contribute to the smooth operation of the library service. They should be regarded as an integral part of the library's staff.

\subsubsection{The composition of the staff}

The composition of the staff should, as far as possible, reflect the make-up of the population it serves. For example, in a community with a significant number of people from a particular ethnic group within the community, the library staff should include members of that group. The same can be said for multiple language groups. Reflecting these diversities within the population demonstrates that the library is a service for everyone and seeks to attract customers from all sections of the public. Libraries should also be in accord with local and national (governance) employment laws. 


\section{$5.4 \quad$ Ethical standards}

Public library staff have a responsibility to maintain high ethical standards in their dealings with the public, other members of staff and external organisations. All members of the public should be dealt with on an equal basis and every effort must be made to ensure that information provided is as full and accurate as possible. Library staff must not allow their personal attitudes and opinions to determine which members of the public are served and what materials are selected and displayed. The public must have confidence in the impartiality of the library staff if the library is to meet the needs of all members of the community. Library associations in some countries have developed codes of ethics, which can be used as models to introduce similar codes elsewhere. The IFLA/FAIFE website includes details of over 20 codes of ethics for librarians from various countries.

\subsection{The duties of library staff}

The operation of a library should be a team effort with a close working relationship between all members of staff. It is important, however, that staff are used primarily for tasks related to their skills and qualifications. It is a wasteful use of scarce resources, for example, for qualified librarians to regularly carry out routine circulation functions. For the same reason it is not necessary to have a qualified librarian in every library regardless of size or circulation rate. Small libraries open for limited hours do not require the continuous presence of a qualified librarian. They should however be under the supervision of a member of the qualified staff. All customers should have access to a qualified librarian whether in person, by telephone or online. Staff should have a written agreement at the time of their appointment, which clearly states their duties and responsibilities. These should not be changed without consulting the member of staff involved.

\subsection{Staffing levels}

The number of staff required in each library service will be affected by a range of factors, for example, the number of library buildings, their size and layout, the number of departments within each building, the level of use, services provided beyond the library and requirements for specialist staff. Where some services are provided or supplemented by a regional or national central agency this will have an impact on the number of staff required at the local level. The level of available resources is also a critical factor. 
A method of developing an appropriate staffing level for a library service would be to carry out a process of bench-marking with libraries of comparative size and similar characteristics.

\subsection{Education of librarians}

Qualified librarians will have undertaken a degree or post-graduate courses at a school of library and information studies. To ensure that they remain in touch with the latest developments, librarians should maintain a process of continuing professional development on a formal and informal basis. It is important that public librarians try to maintain close links with the schools of librarianship (and vice versa) in their country and are fully aware of course content. Whenever possible they should participate in the work of the library and information studies schools, for example, by contributing lectures, assisting in interviewing of prospective students, providing internships and other appropriate forms of co-operation.

\subsection{Training}

Training is a vital element of the activities of a public library. There must be a planned and continuous programme of training for staff at all levels, which should include both full-time and part-time staff. The rapid developments in information technology make the need for regular training even more essential, and the importance of networking and access to other information sources should be included in training programmes. Specialist and support staff should receive induction training in the functions and purpose of the public library and the context in which it operates.

In budgeting for the implementation of new systems, an element should be included for training. In large library services a post of training or personnel officer should be created to plan and implement the training programme. To ensure funds are available for training a set percentage of the budget should be earmarked for this function.

- It is recommended that $0.5 \%-1 \%$ of the total library budget should be earmarked for training purposes.

- Training is offered to staff on site and via the web by FL (USA) regional support centers. <http://www.neflin.org/> and <http://www.tblc.org/training/index.php> 
This level of funding for training should be maintained at times of budget reductions as the need for a well-trained staff is very important in such circumstances.

\subsubsection{Mentoring}

An effective and economical method of training is to introduce a system of mentoring. New staff work with a more experienced colleague who provides guidance and training. The mentor should be able to advise the new member of staff about issues relating to their work and employment. A checklist of the training provided by the mentor should be maintained to ensure that it is carried out effectively.

\subsubsection{Contacts}

In addition to in-service training, staff should be given opportunities to attend short courses in person or via the Internet, and conferences relevant to their ability to carry out their work. They should be encouraged to be active members of the relevant library association, as this creates links with other library staff and provides opportunities for an exchange of ideas and experience. It may also be possible to arrange staff exchanges with staff in other libraries, either in the same country or in a similar library in another country, which can be a valuable experience for all those involved.

\subsection{Career development}

In order to motivate and retain skilled staff, opportunities for career development should be available at all levels. A scheme of performance review should be in place that provides staff with an evaluation of current performance and guidance in improving and developing their skills. These periodic reviews also present an opportunity to mentor and direct career progression. Post employment (or continuing education) training provided by professional organisations and public libraries is a vital ingredient contributing to career development as well.

\subsection{Working conditions}

All library staff should have satisfactory working conditions, and the conditions of employment should be clearly stated in the agreement given to the new member of staff when they are employed. Salaries 
should be at a level appropriate to the level of work being undertaken and competitive with other similar jobs in the community.

\subsubsection{Health and safety}

The health and safety of staff must be a high priority and policies and procedures put in place to reduce risks. Consideration should be given to:

- good working conditions for staff

- ergonomically designed furniture and equipment

- availability of technical aids for employees with special needs and disabilities

- the drawing up of evacuation plans and their testing on a regular basis

- identified health and safety risks being rectified at the earliest opportunity

- ensuring that all equipment and cabling conforms with recognised safety standards

- the establishment of a staff health and safety committee

- appointment and training of staff as first-aid officers and fire wardens

- provision of safety devices for staff, particularly when staff work at nights or away from the library

- providing advanced driver training for staff who drive library vehicles

- protective clothing when required

- limiting the weight of cartons and loads on book trolleys.

Public libraries are often open for long hours including evenings and weekends. In creating work schedules for staff every effort should be made to ensure that their working hours provide them with adequate time off at appropriate times for social activity. It is vital that good labour relations are maintained and fostered with staff.

\subsubsection{Problem customers}

In any building freely accessible to the public, staff will occasionally encounter customers who behave in an unpleasant and anti-social manner. Staff should be trained in how to deal with such situations and have internal communication systems which can alert other staff. Full records of such occurrences should be kept. A system should be developed to support library staff who may deal with these situations, involving other staff such as security guards, or government social work- 
ers. A strong realtionship with all relevant community agencies is very important - so if staff are in situations which they are not qualified or able to handle, they and the library will have ready backing.

\subsection{Volunteers}

Where a library uses volunteer help from individuals in the community to assist library staff, a written policy should be in place defining the tasks of these volunteers and their relationship to the library operation and staff. Volunteers should not be used as a substitute for paid staff (see volunteer policies within Sample policies in this chapter's resource list).

- The Greenfield Public Library, MA (USA) Volunteer Programme is designed to expand and enhance public service to the community. Volunteers generally provide support services to paid staff; work on special projects; or deliver library materials to the homebound. Volunteers are expected to act in accordance with library human resouces policies and to reflect the library's positive customer service attitude. <http://www.greenfieldpubliclibrary.org/Volunteer.html>

\section{Resources}

Cohn, J. \& Kelsey, A. (2006). Staffing the modern library. New York, NY: NealSchuman Publishers, Inc.

Gorman, M. (2003). The enduring library: technology, tradition, and the quest for balance. Chicago: American Library Association.

Goodrich, J. (2007). Human resources for results: The right person for the right job. Chicago: American Library Association.

Haley, C. K. (2009). Online Workplace Training in Libraries. Information Technology and Libraries.

(http://www.ala.org/ala/mgrps/divs/lita/ital/272008/2701mar/haley_html.cfm accessed 20/11/09)

IFLA. (n.d.) Professional codes of ethics for librarians.

(http://www.ifla.org/en/faife/professional-codes-of-ethics-for-librarians)

Jain, P. (2005). "Strategic human resource development in Botswana." Library Management (26) 6/7: pp: 336-350.

Jenkins, H. et. al. (2006). Confronting the Challenges of Participatory Culture: Media Education for the $21^{\text {st }}$ Century. Newmedialiteracies.org. Chicago, IL.: The MacArthur Foundation. 
(http://www.newmedialiteracies.org/files/working/NMLWhitePaper.pdf accessed 15/11/09).

Mid-Huston Library System (n.d.) Trustee resources: Sample public library policy and development tips.

(http://midhudson.org/department/member_information/library_policies.htm accessed 3/09/2010)

Moran, B., Ed. (2003) Training skills for library staff. Lanham, Md: Rowman \& Littlefield Publishing Group, Inc.

Oh, K. \& Yunkeum, K. (2005). Developing a dynamic Korean public library system. (http://archive.ifla.org/IV/ifla72/papers/130-Oh_Chang-en.pdf accessed 12/11/09).

Preer, J. (2008). Library ethics. Littleton, CO: Libraries Unlimited.

Pugh, L. (2005). Managing $21^{\text {st }}$ century libraries. Lanham, Md.: Scarecrow Press.

Rubin, R. (1991). Human resource management in libraries: theory and practice. New York, NY: Neal-Schuman Publishers, Inc.

Todaro, J. \& Smith, M.L. (2006). Training library staff and volunteers to provide extraordinary customer service. New York: Neal-Schuman Publishers.

Online Computer Library Center (OCLC). (n.d.). "Webjunction: Where librarians and library staff connect, create and learn."

(http:/ /www.webjunction.org accessed 1/01/2010).

Whitmell, V. Ed. (2005). Staff planning in a time of demographic change. Lanham, Md.: Scarecrow Press. 
